JosÉ MARTí 


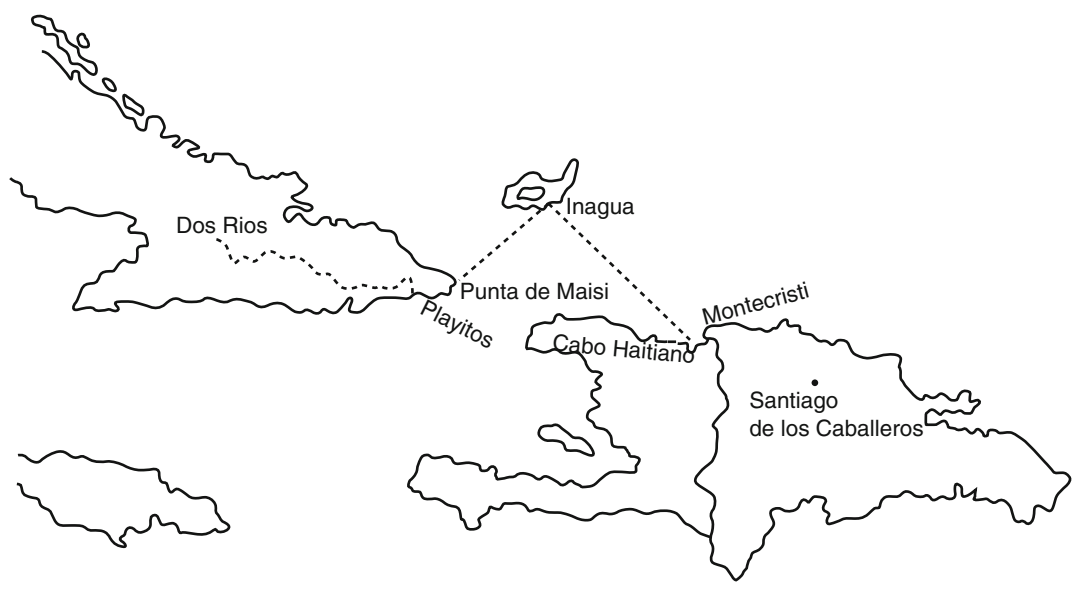




\section{JosÉ MARTÍ: AN INTRODUCTION}

Oscar Montero 


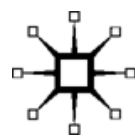

JOSÉ MARTí

Copyright (C) Oscar Montero, 2004.

Softcover reprint of the hardcover 1st edition 2004 978-1-4039-6286-7

All rights reserved. No part of this book may be used or reproduced in any manner whatsoever without written permission except in the case of brief quotations embodied in critical articles or reviews.

First published 2004 by PALGRAVE MACMILLANTM

175 Fifth Avenue, New York, N.Y. 10010 and

Houndmills, Basingstoke, Hampshire, England RG21 6XS.

Companies and representatives throughout the world.

PALGRAVE MACMILLAN is the global academic imprint of the Palgrave Macmillan division of St. Martin's Press, LLC and of Palgrave Macmillan Ltd. Macmillan ${ }^{\circledR}$ is a registered trademark in the United States, United Kingdom and other countries. Palgrave is a registered trademark in the European Union and other countries.

Brief excerpts from A Coney Island of the Mind, copyright (c) 1958 by Lawrence Ferlinghetti. Reprinted by permission of New Directions Publishing Corp.

ISBN 978-1-349-52715-1ＩSBN 978-1-4039-7363-4 (eBook)

DOI $10.1057 / 9781403973634$

\section{Library of Congress Cataloging-in-Publication Data}

Montero, Oscar, 1947-

José Martí : an introduction / Oscar Montero.

p. $\mathrm{cm}$.

Includes bibliographical references and index

ISBN 978-1-349-52715-1 (pbk. : alk. paper)

Martí, José, 1853-1895-Exile-New York (N.Y.) 2. Martí, José, 18531895-Views on the United States. 3. United States-Civilization-19 century 4. United States-History-1865-1898 I. Title

F1783.M38M645 2003

$972.91^{\prime} 05^{\prime} 092-d c 22$

2003058139

A catalogue record for this book is available from the British Library.

Design by Kolam Information Services Pvt. Ltd, Pondicherry, India.

First edition: April 2004

10987654321 
A mi madre Lilia Díaz Valdés 
This page intentionally left blank 


\section{CONTENTS}

Acknowledgments

Prologue: from Coney Island to Dos Ríos

1. Coney Island: Alone in a Crowd 21

2. The New Woman and the Anxieties of Gender 36

3. Against Race 60

4. Pan-Americanism's Empty Train 86

5. Bilingual Emerson 106

6. Martí Faces Death 124

Bibliography

$\begin{array}{ll}\text { 1. Works Cited } & 150\end{array}$

2. Martí in English 155 
This page intentionally left blank 


\section{A C KN OWLEDGEMENTS}

$\mathrm{T}_{1}$ here are forms of collaboration that are not credited in the list of works cited. A debt is owed not just to those whose criticism and scholarship helped me to write this book but to others who offered suggestions, opened spaces in which to air out questions and gave their enthusiasm and support. It is satisfying to look back on the work nearly completed, edit the memory of the rough patches and acknowledge the help of others.

Antonio Vera-León read the manuscript and offered sharp comments, which I used during revisions, especially in the prologue. His intelligence, warmth and generosity are much appreciated. I thank my friends Licia Fiol-Matta and José Quiroga, editors of this series, for their interest in my work on Martí, long before it took its present form. During the years I worked on this book, I was invited to lecture, participate in panels and give courses on Martí. I thank the friends and colleagues who provided these opportunities to present my work. On many occasions, my conversations with José Gomariz helped me to think of new ways to tackle one problem or another.

Colleagues, friends and family gave me or sent me books, articles and clippings, which were often useful and always a pleasure to receive. One such gift was a book that does not appear in the works cited, although I consulted it often, the Atlas histórico biográfico José Martí (historical, biographical José Martí atlas), given to me by Martí scholars Ibrahim Hidalgo and Pedro Pablo Rodríguez. Nuria Gregori gave me a copy of her facsimilar edition of Martís diary, which helped me not only to unravel some of its riddles but also to have a sense of its physical reality, frayed pages crisscrossed with Martís writing, his erasures and corrections.

When I needed the complete works of Martí, my cousin Raimundo Montero found me a set in Havana. I doubt I could have completed this book without those volumes on hand in my office here in New York. My aunt in Cuba, Yara Díaz, sent me numerous articles and photographs; she, my late aunt Ana Díaz, and my mother Lilia, to whom I dedicate this book, have kept alive for me a connection to Cuban history and culture that is also part of the story of our family.

In my courses at Lehman College and The Graduate Center, City University of New York, the questions and suggestions of students helped me to reconsider many aspects of this book. I was grateful for their patience with my enthusiasm for Martí and happy when they sometimes shared it. Parts of chapters 2 and 3 were published in the electronic journal Ciberletras, whose editors Cristina Guiñazú and Susana 
Haydu I thank. Ella Pearce, my editor at Palgrave, offered her enthusiasm and support from the time I first proposed this book. I thank her and production editor Sonia Wilson for overseeing the copyediting and guiding the book through the process of publication.

I am grateful for my family, for their love and support, even when great distances and insurmountable barriers have separated us. I thank Johnny Loflin, my partner of many years, for our love, for always being there and for knowing when not to be.

Oscar Montero New York, N. Y. December 3, 2003 